Original Article

\title{
PHYTOCHEMICAL AND ANTIMICROBIAL ACTIVITY OF THE LEAVES OF LANNEA KERSTINGII ENGL \& K. KRAUSE (ANACADIACEAE)
}

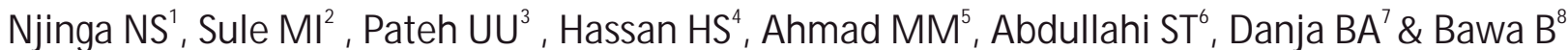 \\ ${ }^{1,6}$ Lecturers, Department of Pharmaceutical \& Medicinal Chemistry, University of Ilorin, ${ }^{2}$ Professor, ${ }^{4}$ Senior Lecturer, \\ Department of Pharmaceutical \& M edicinal Chemistry, ${ }^{3}$ Associate Professor \& Dean, Faculty of Pharmaceutical \\ Sciences, Ahmadu Bello University, Zaria, ${ }^{5}$ Pharmacist, Dr. Gwamna Awan M emorial Hospital, Kakuri, \\ 'Lecturer, Department of Chemical Sciences, Faculty of Science, Federal University Kashere, Gombe, \\ ${ }^{8}$ Researche Scholar, National Agency for Food and Drugs Administration and Control (NAFDAC), Nigeria.
}

\section{Correspondence :}

Njinga N.S.

Lecturer, Department of Pharmaceutical \& M edicinal Chemistry, Faculty of Pharmaceutical Sciences, University of Ilorin.

\section{Abstract :}

E-mail : ngastanjin@yahoo.com

The phytochemical and antimicrobial activity of the petroleum ether and crude methanol extracts, chloroform and ethyl acetate fractions of the leaves of Lannea kerstingii were investigated. Phytochemical screening revealed the presence of steroids and triterpenes in the petroleum ether extract, steroid, triterpene, flavonoids and tannins in both crude methanol extract and chloroform fraction while the ethyl acetate fraction contained only flavonoids and tannins. The extracts exhibited antimicrobial activities with zones of inhibition ranging from 17.00 to $21.03,20.10$ to $25.24,25.32$ to 34.02 and 22.28 to $27.20 \mathrm{~mm}$ for petroleum ether extract, methanol extract, chloroform and ethyl acetate fractions respectively. The minimum inhibitory concentration was between $5 \mathrm{and} 10 \mathrm{mg} / \mathrm{ml}$, $5 \mathrm{mg} / \mathrm{ml}$ for the petroleum ether and methanol extract respectively, and between 2.5 and $5 \mathrm{mg} / \mathrm{ml}, 5 \mathrm{mg} / \mathrm{ml}$ for the acetate fractions. The minimum bactericidal concentration for all the extracts was $40 \mathrm{mg} / \mathrm{ml}$ respectively except for chloroform fraction which ranged from 20 to $40 \mathrm{mg} / \mathrm{ml}$. The minimum fungicidal concentration for all the extracts was found to be $40 \mathrm{mg} / \mathrm{ml}$ respectively. This result indicates the broad spectrum antimicrobial potential of L. Kerstingii and justifies the use of this plant in traditional medicine.

Keywords : antimicrobial, phytochemical, barteri, lannea kerstingii

\section{Introduction:}

Humans have practiced the use of plants for the cure of diseases for centuries ${ }^{[1]}$ and these plants are highly esteemed all over the world as a rich source of therapeutic agents for the prevention of disease and ailments. ${ }^{[2]}$ The search for eternal health and longevity and for remedies against pain and discomfort drove early man to explore his immediate natural surroundings and led to the use of many plants, animal products, minerals etc. and the development of a variety of therapeutic agents. ${ }^{[3]}$ This evolving practice is recorded in both folklore and books of

Access this article online Quick Response Code

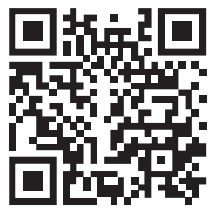
early practitioners.

Despite decades of dramatic progress in their treatment and prevention, infectious diseases remain a major cause of death and debility and are responsible for worsening

the living conditions of many millions of people around the world. Infections frequently challenge the physician's diagnostic skill and must be considered in the differential diagnoses of syndromes affecting every organ system. ${ }^{[4]}$

There is continuous increase in the number of multi-drug resistant microbial strains and the appearance of strains with reduced susceptibility to antibiotics. Examples include methicillin-resistant staphylococci, pneumococci resistant to penicillin and macrolides, vancomycin-resistant Enterococci as well as multi-drug resistant gram-negative organisms. ${ }^{[5]}$ There is an urgent need to control antimicrobial resistance by improved antibiotic usage and reduction of hospital cross-infection and search for newer and safer antibiotics. ${ }^{[6]}$

Lannea kerstingii is a tree with a height of $12 \mathrm{~m}$ and $40 \mathrm{~cm}$ in diameter, with a wide-spreading and relatively dense crown. The bark is smooth to slightly fissured, fissures spiral around the trunk (spiral grain), pale grey with pinkish, 
white-striped slash. ${ }^{[7]}$ L. kerstingii Engl. and K. Krause (Anacardiaceae) is widely utilized in traditional medicine by various cultures worldwide; a decoction of the back is used to treat swellings, ${ }^{[8]}$ infusion of the back, leaves and bud is used for flatulence, the fruit is used against rickets and scurvy. The plant has been reported for the treatment of diarrhoea, ${ }^{[9]}$ gastritis, rheumatic, sterility, intestinal helminthiasis. ${ }^{[10]}$

\section{Materials and Methods :}

Plant material collection and extraction

The plant was collected in M ay, 2011 at Zaria, Kaduna State, Nigeria. It was then taken to the Herbarium of the Department of Biological Science, Ahmadu Bello University, Zaria for identification. It was identified by comparison with a herbarium specimen (voucher specimen 1832). After identification, the leaves were removed and dried under shade. The size was reduced using mortar and pestle, filtered for homogeneity and kept away from light until further use.

The leaves $(100 \mathrm{~g})$ was extracted exhaustively using sequential solvent extraction. It was extracted with petroleum-ether followed by methanol using maceration method with intermittent shaking and solvents changed every 1 hour. The maceration process was then repeated several times for exhaustive extraction. The extracts were dried under reduced pressure. The dried methanolic extract $(20 \mathrm{~g})$ was then dissolved in distilled water and partition using chloroform, and ethylacetate.

\section{Phytochemical Screening}

Basic phytochemical screening to detect the presence or absence of plant chemical constituents such as alkaloids, tannins, saponins, anthraquinones, flavonoids, cardiac glycoside, anthraquinones, steroids and triterpenoe were carried out using standard procedures ${ }^{[1,12]}$ on the petroleum ether extract, crude methanol extract, chloroform and ethylacetate fractions of the leaves, of $\mathrm{L}$. kerstingii.

\section{Test Organisms}

Reference strains and clinical isolates: Staphylococcus aureus NCTC6571, Streptococci faecalis, Bacillus subtilis, Corynobacterium ulcerane, Methicillin-resistant Staphylococcus aureus (MRSA), Escherichia coli NCTC10418, Klebsiella pneumoniae ATCC 10031, Salmonella typhi ATCC 9184, Shigella dysenteriae, Pseudomonas aeruginosa NCTC6750, and fungi Candida albicans, Candida tropicalis and Aspergillus flavus. were obtained from the Department of Phamaceutical M icrobiology, Faculty of Pharmaceutical Sciences, Ahmadu Bello University, Zaria, Nigeria. All the micro-organisms (clinical isolates) were checked for purity and maintained in slants of agar.

\section{Cultivation and Standardization of Test Organism}

A loop full of each of the test organisms were taken from the agar slant and sub cultured into test tubes containing $20 \mathrm{ml}$ of sterile nutrient agar (for bacteria) and sabouraud dextrose agar medium (for fungi). The test tubes were then incubated for 24 hours at $37^{\circ} \mathrm{C}$ for two days (for bacteria) and $27^{\circ} \mathrm{C}$ for 2-7 days (for fungi). The growth culture was standardized using sterile normal saline to obtain a density of $10^{6} \mathrm{cfu} / \mathrm{ml}$ for bacteria. A sporulated test fungal spores was harvested with $0.05 \%$ Tween 80 in sterile Normal saline and standardized to $10^{6}$ spores $/ \mathrm{ml}$.

\section{Preparation of Culture Media}

The prescribed quantities of the dehydrated bacteriological culture media was weighed and hydrated with distilled water according to the manufacturers specification. Where necessary, gentle heat was applied to aid dissolution and the resultant suspensions were dispensed into clean bottles and sterilized at $121^{\circ} \mathrm{C}$ for 15 minutesin an Adelphi bench autoclave.

Antimicrobial Profile (susceptibility test)

The antibacterial screening was carried out using agar diffusion method. ${ }^{[13]}$ The extract was weighed and dissolved in DMSO to obtain the initial concentrations $(40 \mathrm{mg} / \mathrm{ml})$ of the different extracts. Overnight culture of the various bacteria in blood agar and the fungi in sabouraud dextrose agar slant media were sterilized to produce inoculums size of $10^{6} \mathrm{cfu} / \mathrm{ml}$. The medium was seeded with $0.1 \mathrm{ml}$ of standard inoculums of the micro- 
organism (Mc-Forland 0.5). The inoculums were sprayed evenly by the use of sterile swab over the surface of the medium, the seeded plates were allowed to dry at $37^{\circ} \mathrm{C}$ and $27^{\circ} \mathrm{C}$ for the bacteria and fungi respectively for 30 mins inside incubator. A standard cork borer of diameter $6 \mathrm{~mm}$ was used to cut a well at the centre of each seeded medium used and $0.1 \mathrm{ml}$ of the solution of the extracts was then introduced into each hole on the surface of the medium of each bacteria. In one medium, $0.1 \mathrm{ml}$ of DMSO was introduced to serve as negative control and in another, Spafloxacin and Fluconazole $(10 \mu \mathrm{g} \mathrm{ml})$ to serve as positive control for the bacteria and fungi respectively. The medium was incubated at $37^{\circ} \mathrm{C}$ for 24 hours (for bacteria) and $27^{\circ} \mathrm{C}$ for 2-7 days (for fungi) after which the plates were observed for zones of inhibition. The zones of inhibition were measured with a transparent ruler and the result recorded.

Determination of M inimum Inhibitory Concentration This was done using broth dilution method. ${ }^{[14]}$ In this method, 10ml nutrient broth (prepared according to manufacturers specifications) was dispensed into test tubes and sterilized at $121^{\circ} \mathrm{C}$ for 10 minutes and allowed to cool. M c-Forland'sturbidity standard scale number 0.5 was prepared to give a turbid solution. Normal saline was inoculated with each of the test micro-organisms and incubated at $37^{\circ} \mathrm{C}$ for 6 hours to make a turbid suspension of the micro-organisms. After incubation, dilution of the micro-organism in DMSO was done until the turbidity $\left(1.5 \times 10^{6} \mathrm{cfu} / \mathrm{ml}\right)$ matched that of the Mc-Forland scale by visual comparison. Two fold serial dilution of the extract in the broth was done to obtain the following concentrations; $20 \mathrm{mg} / \mathrm{ml}, 10 \mathrm{mg} / \mathrm{ml}, 2.5 \mathrm{mg} / \mathrm{ml}, 1.25 \mathrm{mg} / \mathrm{ml}$ and $0.625 \mathrm{mg} / \mathrm{ml}$. From the suspension of the micro-organism in DMSO, $0.1 \mathrm{ml}$ was inoculated into the different concentrations of the extract in the nutrient broth. The broths were incubated at $37^{\circ} \mathrm{C}$ for $24 \mathrm{hrs}$ (for bacteria) and $27^{\circ} \mathrm{C}$ for 2-7 days (for the fungi) after which the test tubes were observed for turbidity. The lowest concentration of the extract in the broth which shows no turbidity represents the MIC. The results after 24 hour were recorded.
Determination of Minimum Bactericidal Concentration (MBC)

Blood agar was prepared according to manufacturer's instruction, sterilized at $121^{\circ} \mathrm{C}$ for 15 minutes. It was poured into sterile petri-dishes. The plates were allowed to cool and solidify. The contents of the M IC test tubes in the serial dilution were then sub-cultured on to the prepared plates and the plates were then incubated at $37^{\circ} \mathrm{C}$ for 24 hours (for bacteria) and $27^{\circ} \mathrm{C}$ for $2-7$ days (for the fungi) after which the plates were observed for growth. The plate without growth represents the minimum bactericidal concentration. After 24 hours the results were recorded. ${ }^{[14,15]}$

\section{Results:}

The leaves of L. kerstingii contained more methanol soluble phytochemicals (32.44\%) followed by petroleum ether (30.2\%). The yield of the chloroform and ethyl acetate fractions were found to be 10.05 and $8.5 \%$ respectively (table 1).

The crude methanolic extract and chloroform fraction were found to contain flavonoids, tannins, steroids and triterpenes. The ethyl acetate fraction of the leaves of $L$. kerstingii was found to contain only flavonoids and tannins. While the petroleum ether extract contains only steroids and triterpenes (table 2).

The petroleum ether, the crude methanol extract and all the other two fractions were inactive against $C$. ulcerane, $P$. aeruginosa, $C$. albicans and $A$. flavus. The crude methanol and the petroleum ether extract were also inactive against $\mathrm{S}$. typhi. All the extracts were active against $\mathrm{S}$. aureus, $\mathrm{S}$. faecalis, B. subtilis, MRSA, E. coli, K. pneumonia, S. dysentariae and the fungi $C$. tropicalis. The chloroform fraction and the ethyl acetate fraction were also active against $\mathrm{S}$. typhi (Table 3). The zone of inhibition of the crude methanol extract ranged from $20.10 \mathrm{~mm}$ (E. coli) to $25.12 \mathrm{~mm}$ (S. dysentariae), that of petroleum ether ranged from $17.00 \mathrm{~mm}$ (E. coli and C. tropicalis) to $21.03 \mathrm{~mm}$ (S. aureus). The chloroform fraction showed high activity when compared to the ethyl acetate fraction with zone of 
inhibition ranging from $25.32 \mathrm{~mm}$ (S. typhi ) to $34.02 \mathrm{~mm}$ (B. subtilis). While that of ethyl acetate ranged from $22.28 \mathrm{~mm}$ (S. typhi) to $27.20 \mathrm{~mm}$ (B. subtilis, K. pneumonia and S. dysentariae) (table 3).

The MIC of the crude methanol and ethyl acetate fractions were $5 \mathrm{mg} / \mathrm{ml}$ respectively. That of the chloroform extract was found to be $2.5 \mathrm{mg} / \mathrm{ml}$ for $\mathrm{S}$. faecalis, B. subtilis, $\mathrm{K}$. pneumonia, S. typhi and S. dysentariae and $5 \mathrm{mg} / \mathrm{ml}$ for $\mathrm{S}$. aureus, MRSA, E. coli and C. tropicalis respectively while the MIC of the petroleum ether extract was $5 \mathrm{mg} / \mathrm{ml}$ for $\mathrm{S}$. aureus, B. subtilis and $\mathrm{K}$. pneumonia and $10 \mathrm{mg} / \mathrm{ml}$ for $\mathrm{S}$. faecalis, MRSA, E. coli, S. dysentariae and C. tropicalis respectively as shown in table 4.

Table 2 : phytochemical constituents present in the different extracts of the leaves of Lannea kerstingii

\begin{tabular}{lcccc}
\hline Constituents & Petroleum & Crude & Chloroform & Ethyl \\
\hline & ether & methanol & fraction & acetate \\
extract & extract & & fraction \\
Anthraquinones & - & - & - & - \\
Flavonoids & - & + & + & + \\
Tannins & - & + & + & + \\
Alkaloids & - & - & - & - \\
Coumarins & - & - & - & - \\
Saponins & - & - & - & - \\
Steroids and triterpenes & + & + & + & - \\
Cardiac Glycoside & - & - & - & - \\
\hline
\end{tabular}

Key: - = not present, += present

Table 3 : Zone of inhibition of crude methanol extract, chloroform and ethyl acetate fraction of the leaves of $L$. kerstingii.

\begin{tabular}{|c|c|c|c|c|c|c|}
\hline \multirow[t]{2}{*}{ TEST ORGANISM } & \multicolumn{6}{|c|}{ ZONE OF INHIBITION (mm) } \\
\hline & $\begin{array}{c}\text { Petroluem } \\
\text { ether fraction }\end{array}$ & $\begin{array}{c}\text { Crude } \mathrm{CH}_{3} \mathrm{OH} \\
\text { extract }\end{array}$ & $\begin{array}{c}\mathrm{CHCl}_{3} \\
\text { fraction }\end{array}$ & $\begin{array}{c}\text { Ethyl acetate } \\
\text { fraction }\end{array}$ & Sparflo-zin & $\begin{array}{c}\text { Flucona } \\
\text {-zole }\end{array}$ \\
\hline S. aureus NCTC6571 & 21.03 & 20.10 & 27.30 & 25.10 & 27.00 & \\
\hline S. faecalis & 19.10 & 21.23 & 30.10 & 24.10 & 32.02 & \\
\hline B. subtilis & 20.10 & 25.24 & 34.02 & 27.20 & 47.00 & \\
\hline C. ulcerane & 0.00 & 0.00 & 0.00 & 0.00 & 32.11 & \\
\hline M ethicillin-resistant S. aureus (M RSA) & 19.02 & 22.06 & 28.41 & 24.21 & 37.03 & \\
\hline E. coli NCTC10418 & 17.00 & 20.10 & 27.24 & 26.22 & 37.10 & \\
\hline K. pneumoniae ATCC 10031 & 20.42 & 24.10 & 31.34 & 27.20 & 47.02 & \\
\hline S. typhi ATCC 9184 & 0.00 & 0.00 & 25.32 & 22.28 & 32.23 & \\
\hline S. dysentariae & 19.30 & 25.12 & 32.16 & 27.20 & 39.33 & \\
\hline P. aeruginosa NCTC6750 & 0.00 & 0.00 & 0.00 & 0.00 & 29.22 & \\
\hline C. albicans & 0.00 & 0.00 & 0.00 & 0.00 & & 32.00 \\
\hline C. tropicalis & 17.00 & 22.03 & 27.00 & 24.10 & & 29.21 \\
\hline A. flavus & 0.00 & 0.00 & 0.00 & 0.00 & & 34.01 \\
\hline
\end{tabular}

The M BC of the petroleum ether and the crude methanol extracts were above $40 \mathrm{mg} / \mathrm{ml}$ for all the organisms except for B. subtilis whose $M B C$ was $40 \mathrm{mg} / \mathrm{ml}$ for the methanol extract. The chloroform extract showed MBC/MFC for all tested organism except for $B$. subtilis whose $M B C$ was $20 \mathrm{mg} / \mathrm{ml}$. The ethyl acetate showed $M B C$ of $40 \mathrm{mg} / \mathrm{ml}$ for S. aureus, B. subtilis, E. coli and K. pneumonia and M FC of above $40 \mathrm{mg} / \mathrm{ml}$ for C. tropicalis (table 5 )..

Table 1 : \% yield of the different extracts obtained from the extraction of the leaves of Lannea kerstingii.

\begin{tabular}{lccc}
\hline Fraction & Colour & Weight & \% yield \\
\hline Petroleum ether extract & Dark green & $30.02 \mathrm{~g}$ & $30.2 \%$ \\
Crude methanol extract & Dark green & $32.44 \mathrm{~g}$ & $32.44 \%$ \\
Chloroform fraction & Light green & $2.01 \mathrm{~g}$ & $10.05 \%$ \\
Ethyl acetate fractopm & Light green & $1.74 \mathrm{~g}$ & $8.5 \%$ \\
\hline
\end{tabular}


Table 4: M inimum Inhibitory Concentration of petroleum ether and crude methanol extract, chloroform and ethyl acetate fractions of the leaves of L. kerstingii against Test Organisms

\begin{tabular}{|l|c|c|c|c|}
\hline TEST ORGANISM & \multicolumn{4}{|c|}{ M IC(mg/ ml) } \\
\hline & $\begin{array}{c}\text { Petroleum } \\
\text { ether extract }\end{array}$ & $\begin{array}{c}\text { Crude } \\
\text { methanol extract }\end{array}$ & $\begin{array}{c}\text { Chloroform } \\
\text { fraction }\end{array}$ & $\begin{array}{c}\text { Ethyl } \\
\text { acetate fraction }\end{array}$ \\
\hline S. aureus NCTC6571 & 5 & 5 & 5 & 5 \\
\hline S. faecalis & 10 & 5 & 2.5 & 5 \\
\hline B. subtilis & 5 & 5 & 2.5 & 5 \\
\hline M RSA & 10 & 5 & 5 & 5 \\
\hline E. coli NCTC10418 & 10 & 5 & 5 & 5 \\
\hline K. pneumoniae ATCC 10031 & 5 & 5 & 2.5 & 5 \\
\hline S. typhi ATCC 9184 & & & 2.5 & \\
\hline S. dysentariae & 10 & 5 & 5 & 5 \\
\hline C. tropicalis & 10 & 5 & & 5 \\
\hline
\end{tabular}

Table 5 : M inimum Bactericidal / Fungicidal Concentration of petroleum ether and crude methanol extracts, chloroform and ethyl acetate fractions of the leaves of $L$. kerstingii against Test Organism

\begin{tabular}{|l|c|c|c|c|}
\hline TEST ORGANISM & \multicolumn{4}{|c|}{ MBC/M FC (mg/ml) } \\
\hline Staphylococcus aureus NCTC6571 & $\begin{array}{c}\text { Petroleum } \\
\text { ether extract }\end{array}$ & $\begin{array}{c}\text { Crude } \\
\text { methanol }\end{array}$ & $\begin{array}{c}\text { Chloroform } \\
\text { fraction }\end{array}$ & $\begin{array}{c}\text { Ethyl acetate } \\
\text { fraction }\end{array}$ \\
\hline Streptococci faecalis & 40 & 40 & 40 & 40 \\
\hline Bacillus subtilis & 40 & 40 & 40 & 40 \\
\hline M RSA & 40 & 40 & 20 & 40 \\
\hline Escherichia coli NCTC10418 & 40 & 40 & 40 & 40 \\
\hline Klebsiella pneumoniae ATCC 10031 & 40 & 40 & 40 & 40 \\
\hline Salmonella typhi ATCC 9184 & & & 40 & 40 \\
\hline Shegella dysentariae & 40 & 40 & 40 & 40 \\
\hline C. tropicalis & 40 & 40 & 40 & 40 \\
\hline
\end{tabular}

\section{Discussion :}

M ethanol was found to be a better extraction solvent than petroleum ether (table 1) which is with conformity with literature. ${ }^{[16]}$ Flavonoids have been shown to have anti-viral and antimicrobial activities. ${ }^{[17,18]}$ Tannins may exhibit antibiotic activity by complexing extracellular enzymes produced by the pathogens or by interference with the metabolism of the pathogen itself. ${ }^{[19]}$ Thus the antimicrobial activity of the leaves may be due to the presence of flavonoids and tannins (table 2).

The methanol and ethanol extract of the leaves of $L$. kerstingii have been reported to be active against $S$. aureus, E. coli, P. vulgaris, S. typhi, S. lactis, Shigella sp.. ${ }^{[20]}$ This is in line with the current study in which the methanol extract show activity against $\mathrm{S}$. aureus, E. coli and S. dysentariae but inactive against $\mathrm{S}$. typhi (table 3 ). This difference may be due to age, physiological variations, environmental conditions, geographic variations, genetic factors and evolutional differences of the plant ${ }^{[21]}$ or the presence of an antagonist in the extract.

Among the extracts, the petroleum ether fraction is the least active. Its activity is solely due to the presence of steroids and triterpenes present in the fraction (table 2). The chloroform fraction is the most active and its activity is be due to the presence of low molecular weight flavonoids, tannins, steroids and triterpenes (table 2). The results of this study corresponds with several investigation that flowering plants are potential source of antimicrobial substances. ${ }^{[2,23]}$

The low MIC of these extracts (table 3) especially the chloroform fraction showed the extract's activity against both Gram positive and Gram negative bacteria which are associated with different type of infections including urinary tract infections (S. aureus), and typhoid fever (S. typhi). S. aureus is also responsible for a wide variety of 
diseases, including pneumonia, skin and soft tissue infections, and diabetic foot infections. ${ }^{[24]}$ Similarly, $P$. aeruginosa is a common pathogen associated with burn wound infections, keratitis, and respiratory tract infections. ${ }^{[25]}$ The extract also showed activity against $\mathrm{E}$. coli (MIC $5 \mathrm{mg} / \mathrm{ml}$ ) which is the commonest cause of urinary tract infection and accounts for approximately $90 \%$ of first urinary tract infection in young women ${ }^{[15]}$ This indicates the usefulness of this plant in the treatment of urinary tract infection, respiratory tract infections, diabetic foot infections due to its activity against the organisms causing these infections. This result gives scientific base and credence for the claims of the therapeutic capabilities and folkloric usage of the leaves of Lannea kerstingii for the treatment of various ailments.

\section{References}

1. Lesney MS. Nature's Pharmaceuticals: Natural Products from Plants Remain at the Core of Modern M edicinal Chemistry. Today's Chemist at Work. 2004;13(7):26-31.

2. Sharma A, Shanker C, Tyagi L, Singh M, Rao CV. Herbal M edicine for M arket Potential in India: An Overview. Int. J. Plant Sci. 2008;1:26-36.

3. Nair R, Chanda S. Antibacterial activities of some medicinal plants of the Western region of India. TurkishJ. Biol. 2007;31:231-236.

4. Longo DL, Kasper DL, Jameson JL, Fauci AS, Hauser SL, Loscalzo J. Harrison's Principles of Internal Medicine 18th edn. 2012; The M cGraw-Hill Companies Inc, New York.

5. Norrby RS, Nord CE, Finch R. Lack of development of new antimicrobial drugs: a potential serious threat to public health. Lancet. 2005;5: 115119 .

6. Sung WS, Lee DG. In vitro antimicrobial activity and the mode of action of indol-3-carbinol against human pathogenic microorganisms. Biol. Pharm. Bull. 2007;30: 1865-1869.

7. Arbonnier M. Trees, shrubs and lianas of West African dry zones. 2002; CIRAD, M NHN

8. Doka IG, Yagi SM . Ethnobotanical Survey of M edicinal Plants in West Kordofan (Western Sudan). Ethnobot Leaflets. 2009;13: 1409-1416.

9. Njinga NS, Sule MI, Patteh UU, Hassan HS, Usman MA, Haruna MS. Phytochemical and Antidiarrhea Activity of the Methanolic Extract of the Stem Bark of Lannea kerstingii Engl. and K. Krause (Anacardiaceae). J. Nat. Prod. Plant Resour. 2013;3(3):43-47

10. Koné WM , Kamanzi AK, Traoré D, Betschart B. Anthelmintic activity of medicinal plants used in Northern Côte d'Ivoire against intestinal helminthiasis. Pharm. Biol. 2005:43: 72-78.

11. Brain KR, Turner TD. The practical Evaluation of Phytopharmaceutical. 1975; Wright Scientechnica, Bristol.

12. Sofowora A. Medicinal plants and traditional medicine in Africa. $2^{\text {nd }}$ Edn. 1993; Spectrum books limited, Ibadan.

13. Lino A, Deogracios 0 . The in-vitro antibacterial activity of Annona senegalensis, Securidacca longipendiculata and Steanotaenia araliacea-Ugandan M edicinl plants. Afri. Health Sci. 2006;6(1): 31-35

14. Vollekova $A D$, Sochorova R. Isoquinoline Alkaloids from Mahonia aquifolium stem bark is active against Malassezia Sp. Folia. Microbiologica. 2001;46: 107-111.

\section{Conclusion:}

The leaves of Lannea kerstingii contains phytochemicals which possess antimicrobial activity. This study therefore supports the traditional use of Lannea kerstingii for the treatment of various infectious diseases in Nigeria and different regions of the world, and may serve as a good source of novel antibiotics.

\section{Acknowledgment :}

The authors are grateful to the Department of Biological Sciences ABU Zaria for Identification of the plant, the Department of Pharmaceutical M icrobiology, ABU Zaria for provision of micro-organisms, and to M r. Abdullahi M akailu Sabo of the Nigerian Institute of Leather and Science Technology (NILEST) Zaria, for his assistance with the antimicrobial screening.

15. Usman $\mathrm{H}$, Abdulrahman $\mathrm{FI}$, Ladan $\mathrm{AH}$. Phytochemical and Antimicrobial Evaluation of Tribulus terrestris L. (Zygophylaceae) Growing in Nigeria. Res.J Bio. Sci. 2007;2(3): 244-247.

16. Obi VI, Onuoha C. Extraction and characterization method of plants and plant products. In: Biological and Agricultural Techniques. Ogbulie, J. L, and O. J. Ojiako (eds). 2000; Webs media publications, Owerri.

17. Hang T, Jin JB, Cho S, Cyang JC. Evaluation of anti-inflammatory effects of baicalein on dextran sulfate sodium-induced colitis in mice. Planta Medica. 2002:68(2):268-271.

18. Vessal M, Hemmati M, Vasei M. Antidiabetic effects of quercetin in streptozocin induced diabetic rats. Comp. Biochem. Physiol. 2003;135:357364

19. Okuda T, Yoshida T, Hatano T. Ellagitannins as active constituents of medicinal plants. Planta M edica. 1989;55:117-122

20. Adegoke SA, Agada F D, Ogundipe LO. Antibacterial activity of methanol and ethanol leaf extracts of Antidesma venosum and Lannea barteri. African Journal of Microbiology Researc. 7(27), 2013, 3442-3447

21. Figueiredo AC, Barroso JG, Pedro LG, Scheffe JJC. Factors affecting secondary metabolite production in plants: volatile components and essential oils. Flavour Frag. J.. 2008;23(4): 213-226

22. Sandhu DS, Heinrich M. The use of health foods, spices and other botanicals in the Sikh community in London. Phytother. Res. 2005;19: 633-642.

23. M.P. Guptaa, b, *, P.N. Sol 'isa, A.I. Calderon'a, F. Guinneau-Sinclairc, M. Correab,d, C. Galdamesb, C. Guerraa, A. Espinosaa, G.I. Alvendae, G. Roblese, R. Ocampoe. M edical ethnobotany of the Tribes of Bocas del Toro, Panama. J. Ethnopharmacol. 2005;96: 389-401.

24. Shorr AF. Epidemiology and economic impact of meticillin-resistant staphylococcus aureus: review and analysis of the literature. PharmacoEconomics, 2007:25:751-68.

25. M arquart M E, Caballero AR, Chomnawang M, ThibodeauxBA, Twining SS, Callaghan RJ. Identification of a novel secreted protease from Pseudomonas aeruginosa that causes corneal erosions. Invest. Ophthalmol. Vis. . 2005;46:3761-8. 